\title{
Test-Retest Differences of the Speech Discrimination Score in Patients with Hearing Loss
}

\author{
Taehun Lim ${ }^{D}$, Joo Hyung Oh, Junho Hwang, Joon Bum Joo, Ju Eun Cho, and Jong Yang Kim \\ Department of Otorhinolaryngology, National Police Hospital, Seoul, Korea
}

\author{
난청 환자에서 어음명료도 반복 검사 시의 편차 분석 \\ 임태헌 · 오주형 · 황준호 · 주준범 · 조주은 · 김종양 \\ 국립경찰병원 이비인후과
}

\author{
Received November 11, 2020 \\ Revised January 20, 2021 \\ Accepted January 26, 2021 \\ Address for correspondence \\ Jong Yang Kim, MD, PhD \\ Department of Otolaryngology, \\ National Police Hospital, \\ 123 Songi-ro, Songpa-gu, \\ Seoul 05715, Korea \\ Tel $+82-2-3400-1828$ \\ Fax $+82-2-400-0287$ \\ E-mail austin_kim@hanmail.net
}

Background and Objectives The diagnosis of hearing impairment is based on repeated audiometry, including pure tone audiometry (PTA), speech reception threshold test (SRT), and speech discrimination test (SDT). SDT results particularly show a wide discrepancy upon repeated testing, while malingering is suspected when having more than $12 \%$ difference between 3 individual SDT results. Therefore, in this study, we compared the proportion of malingering found in repeated SDT with that found in other audiometric tests and analyzed the characteristics of malingering group in order to reevaluate the current criteria of defining malingering. Subjects and Method We retrospectively assessed the audiometry results of 113 patients (226 ears) with hearing impairment. Each ear was divided into a malingering group and a true hearing loss group. The proportion of ears corresponding to each malingering criterion was compared using a chi-square test. An independent sample t-test was performed to identify the differences between the characteristics between the two groups.

Results The number of ears that met the malingering criteria were $19(8.41 \%)$ in PTA, 15 $(6.64 \%)$ in SRT, and $75(33.19 \%)$ in SDT. There was a significant difference in the proportion of malingering between the 3 hearing test modalities $(p<0.001)$. There was no significant difference in auditory brainstem response, mean age and sex distribution between the malingering group and the true hearing loss group.

Conclusion When conducting repeated SDT, there is a risk of misdiagnosing an actual hearing loss patient as a malingering patient under the current malingering criteria. Therefore, the current criteria on SDT requires reevaluation.

Korean J Otorhinolaryngol-Head Neck Surg 2022;65(1):10-7

Keywords Hearing loss; Malingering; Speech audiometry; Speech discrimination tests.

\section{서 론}

2015년 11월 4일, 국민건강보험법 시행규칙 및 장애인 보장 구 보험 기준 등의 세부사항 고시가 개정됨에 따라, 청각장애 환자에 대한 보청기 지원이 확대되었고, 이로 인해 청각장애

This is an Open Access article distributed under the terms of the Creative Common Attribution Non-Commercial License (https://creativecommons.org/licenses/by-nc/4.0) which permits unrestricted non-commercial use, distribution, and reproduction in any medium, provided the original work is properly cited.
진단을 위해 이비인후과에 내원하는 난청 환자의 수가 늘어 나고 있다.

현재 보건복지부에서 고시하고 있는 청각장애의 진단은 기 본적으로 순음청력검사(pure tone audiometry)를 기준으로 하고 있는데, 검사 결과의 신뢰성 확보 및 위난청의 감별을 위해 총 3회의 반복 검사를 시행하도록 권고하고 있으며, 1 회 의 청성뇌간반응검사(auditory brainstem response, $\mathrm{ABR}$ ) 결과를 확인하여 추가적으로 객관성을 확인하고 있다. 
그런데 현재 고시된 청각장애 등급 중 4급 2호의 경우에는, 순음청력검사 결과와 관계없이 양측 귀의 어음명료도검사 (speech discrimination test) 결과가 모두 50\% 미만인 경우 를 기준으로 하고 있으며, 이 경우에도 역시 3회의 반복 검사 를 통해 그 신뢰성을 확인하고 있는데, 보건복지부에서 고시 한 바에 따르면, 3 회 간의 어음명료도검사 간의 차이가 $12 \%$ 이상인 경우에는 위난청을 감별하도록 하고 있다. 그러나 외 래에서 난청 환자를 대상으로 청각장애 진단을 위해 반복 검 사를 시행하다 보면, 순음청력검사나 어음청취역치(speech reception threshold) 결과에 비해 어음명료도검사에서 많은 편차를 보이며, 이에 따라 위난청 기준에 해당되어 장애 진단 에 어려움을 겪는 경우가 존재한다.

어음명료도검사의 반복 검사 시 위난청 감별 기준 수치의 설정은, 1965년 Chaiklin과 Ventry ${ }^{11}$ 가 같은 세기로 이루어진 영어 단어를 음절 개수에 따라 검사를 시행하여 비교한 연 구에서 어음 검사에 적절한 단어의 음절을 제안하였고, 이후 1980년 Hodgson ${ }^{2}$ 이 순음청력검사 및 어음 검사들의 적절한 방법 및 기준을 소개한 연구에서, 영어 음절을 바탕으로 반복 검사 간 적정 편차를 $12 \%$ 로 제시한 이래로 약 40 여 년간 해당 기준이 사용되어 왔다. 또한 우리나라에서는 1962년 $\mathrm{Hahm}^{3)}$ 에 의해 한글 단음절어표가 개발된 이래로 다양한 어음명료 도검사에서 사용하는 단음절어표를 개발하는 시도는 있었으 나, 어음명료도의 위난청 감별 기준에 대한 연구는 부족한 상태이다.

따라서 본 연구에서는, 청각장애 진단을 위해 이비인후과 에 내원하여 짧은 기간 동안 반복 청력검사를 시행한 난청 환자의 청력검사 결과를 분석하여, 각 청력검사 간 현재 위난 청 기준에 해당하는 편차를 보이는 환자 수를 비교하고, 어음 명료도검사의 위난청 기준인 $12 \%$ 이상인 군과 $12 \%$ 미만인 군으로 나누어 위난청의 잠재성이 있는 특성에 대해 확인하 고, 현재의 기준에 대해 고찰하고자 하였다.

\section{대상 및 방법}

2017년 1월 1일 2019년 12월 31일까지 난청을 주소로 본원 이비인후과 외래에 방문하여 청력검사 시행 후 장애 진단서가 발급된 환자의 양측 귀를 대상으로 하였으며, 기관 내 Institutional Review Board(IRB No. 11100176-202009-HR006)의 승인하에 후향적으로 의무기록과 청력검사 결과지를 검토하였다.

차트 분석 결과 총 113 명의 환자, 226개의 귀가 확인되었다. 각 귀별로 청각장애진단을 위해 시행한 총 3 회의 순음청력검 사, 어음청취역치검사, 어음명료도검사 결과 및 1 회의 청성뇌
간반응검사(ABR) 결과를 수집하였고, 검사별로 3회 간의 검 사값 중 최대값과 최소값의 차를 구하여 위난청의 기준에 해 당하는지를 확인하였다.

순음청력검사는 AudioStar $\operatorname{Pro}^{\mathrm{TM}}$ (GSI, Eden Prairie, MN, $\mathrm{USA}$ )를 사용하여, $125 \mathrm{~Hz}$ 부터 $8 \mathrm{kHz}$ 까지 각 주파수 영역별 로 $5 \mathrm{~dB}$ 간격으로 기도와 골도 청력역치를 구하였으며, 6 분 법 평균치를 계산하여 결과를 기록하였다. 어음청취역치는 각 음절이 같은 세기로 이루어진 두 음절 단어를 환자에게 읽어 주고 따라 말하도록 하여, 환자가 어음을 50\% 정확하게 되풀 이하여 말할 수 있는 가장 낮은 강도를 기록하였다. 어음명료 도검사는 함태영 단음절어표를 이용하여 양측 귀에 각각 서 로 다른 50 개의 단음절 단어를 읽어 주고 똑같이 따라 말한 단어의 개수를 체크하여 백분위로 환산하여 기록하였다.

수집된 226개의 귀에 대하여 반복 청력검사 간 편차값이 각각의 위난청 기준인, 순음청력검사 $10 \mathrm{~dB}$, 어음청취역치검 사 $15 \mathrm{~dB}$, 어음명료도검사 $12 \%$ 에 해당하는 귀의 비율을 확 인하였고, 각 검사별로 위난청 기준에 해당하는 귀의 수가 통 계적으로 유의미한 차이가 있는지 평가하였다.

난청 환자에서 반복 어음명료도 검사 시 적절한 위난청 기 준값을 확인하기 위해 두 가지 방법을 사용하였다. 첫째로 본 연구에 포함된 전체 귀의 어음명료도 편차값을 크기 순으로 나열하였을 때, 위난청 환자의 비율이 $10 \%$ 미만으로 나타나 는 값을 확인하였다. 둘째로 반복 순음청력검사와 어음청취 역치검사상 위난청에 해당하는 귀를 위난청 확진으로 설정 하여, 어음명료도검사의 편차값에 대해 receiver operating characteristic curve(ROC 곡선)를 산출한 후 최적 설정값을 구하여 민감도와 특이도를 확인하고, 특이도가 $90 \%$ 이상으 로 나타날 수 있는 설정값을 확인하였다.

어음명료도 반복 검사 시 위난청 기준에 해당하는 그룹과 정상 범위인 그룹 간의 비교를 위해, 나머지 청력검사 결과들 을 통제하고자 하였다. 먼저 어음명료도검사 결과가 $0 \%$ 에 수 렴하여 검사 간 편차가 매우 적어 통계 분석 시 잠재적 바이 어스로 작용할 가능성이 있는 청력 손실이 $80 \mathrm{~dB}$ 이상인 귀 는 제외하였다. 이에 따라 장애 등급 3 급 이상(두 귀의 청력 손실이 각각 $80 \mathrm{~dB}$ 이상)인 환자 17 명, 34 개의 귀를 모두 제 외하였고, 장애 등급 4 급 1 호, 4 급 2 호, 5 급, 6 급 환자 중에서 일측의 청력 손실이 $80 \mathrm{~dB}$ 이상인 귀 29개를 제외하였다. 나 머지 163 개의 귀 중, 순음청력검사와 어음청취역치검사상 위 난청 기준에 해당하는 귀 27 개를 연구에서 제외하였고, 최종 적으로 남은 136 개의 귀에 대해서 순음청력검사 6 분법 평균 과 $\mathrm{ABR}$ 역치를 비교하여 선별된 귀들의 난청 신뢰도를 확보 하고자 하였다. 비교 결과 116 개의 귀에서 순음청력검사 평균 과 $10 \mathrm{~dB}$ 이내의 차이를 보였고, 20 개의 귀에서 $\mathrm{ABR}$ 값이 10 
$\mathrm{dB}$ 이상 크게 나타났으나, 이들 모두 수평형이 아닌 하향형 난청으로 인한 차이로 판단되어 정상 난청으로 분류하고 분 석에 포함하였다(Fig. 1).

최종적으로 분석에 포함된 136 개의 귀를 대상으로, 전체 그룹과 3회의 순음청력검사 결과의 평균이 40 이상 60 미만 인 그룹, 60 이상 70 미만인 그룹, 70 이상 80 미만인 그룹으 로 나누어 각 그룹별로 3 회의 어음명료도검사 간의 차이값이 $12 \%$ 이상인 그룹과 미만인 그룹 간 성별, 나이 및 $\mathrm{ABR}$ 결과 의 차이를 확인하기 위해 통계적 분석을 시행하였다.

통계 분석은 SPSS Statistics 25.0(IBM Corp., Armonk, $\mathrm{NY}, \mathrm{USA}$ ) 프로그램을 사용하였다. 청력검사들 간 위난청에 해당하는 환자 수 비교에는 카이 제곱 검정을 사용하였고, 각 청력 그룹별 어음명료도검사의 위난청과 정상 범위 그룹 간 나이와 $\mathrm{ABR}$ 의 차이 분석에는 독립 표본 $\mathrm{T}$ 검정을 수행하였 으며, 성별 차이 분석에는 카이 제곱 검정을 수행하였다. 통 계적 유의성은 $p<0.05$ 를 기준으로 평가하였다.

\section{결 과}

각 청력검사별 위난청 귀 비율 비교에 포함된 226개의 귀에 대한 특징 분석 결과, $\mathrm{ABR}$ 역치 평균은 $74.47 \mathrm{~dB}$ 로 나타났 고, 평균 나이는 69.85세, 성별의 분포는 남자 162명(71.68\%), 여자 64명(28.32\%)으로 나타났다. 순음청력검사 결과를 통한 평균 청력 분포는 40 59 dB가 24개(10.62\%), 60 69 dB가 101 개(44.69\%), 70 79 dB가 38개(16.81\%), $80 \mathrm{~dB}$ 이상이 63 개(27.88\%)인 것으로 확인되었다(Table 1). 어음명료도 반복 검사상 위난청에 해당하는 군과 정상 범위 군의 비교를 위해 선별한, 청력 범위 $40 \mathrm{~dB}$ 이상, $80 \mathrm{~dB}$ 미만이면서 다른 반복

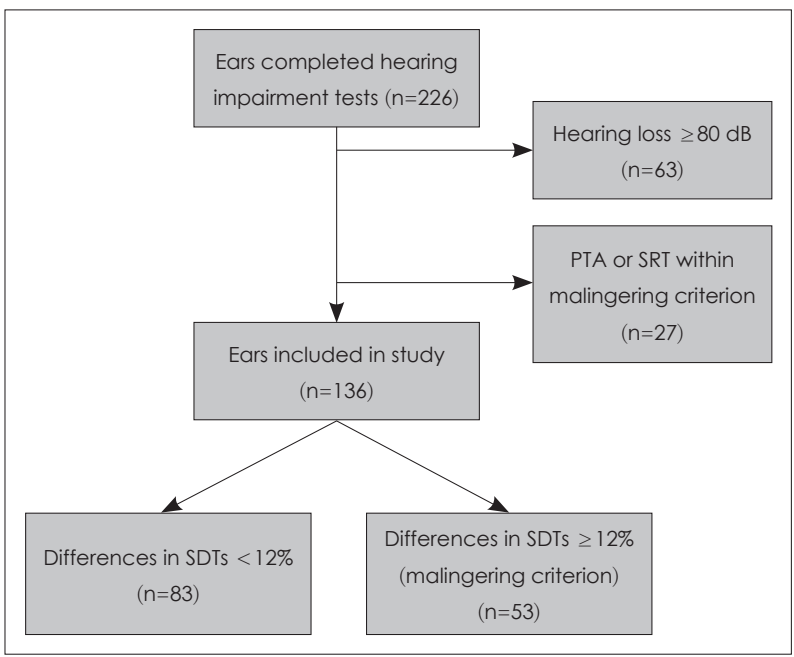

Fig. 1. Summary of the data collection. PTA: pure tone audiometry, SRT: speech reception threshold test, SDT: speech discrimination test.
청력검사상 위난청에 해당되지 않는 귀는 총 136 개로, $\mathrm{ABR}$ 역치 평균은 $71.67 \mathrm{~dB}$ 였고, 평균 나이는 73.98 세, 성별은 남 자 103 명(75.74\%), 여자 33명(24.26\%)이었다. 평균 청력 분포 는 40 59 $\mathrm{dB}$ 가 20개(14.70\%), 60 69 $\mathrm{dB}$ 가 90개(66.18\%), 70 79 $\mathrm{dB}$ 가 26개(19.12\%)로 나타났다(Table 1).

총 226개의 귀 중 각 청력검사별로 반복 검사 간 편차의 값 이 위난청 기준에 해당되는 귀의 비율을 확인한 결과, 순음청 력검사값 간 편차의 평균은 $3.49 \mathrm{~dB}$ 였으며, $10 \mathrm{~dB}$ 이상 차이 가 나타난 귀는 총 19 개로 전체의 $8.41 \%$ 로 나타났다(Fig. 2). 어음청취역치검사값 간 편차의 평균은 $4.12 \mathrm{~dB}$ 였고, $15 \mathrm{~dB}$ 이상 차이가 나타난 귀는 총 15 개로 전체의 $6.64 \%$ 에 해당되 었다(Fig. 3). 어음명료도검사값 간 편차는 평균 9.39\%였고, 위난청 기준 값인 $12 \%$ 이상의 차이를 보인 귀의 수는 총 75 개로 전체의 $33.19 \%$ 에 해당하는 것으로 나타났다(Fig. 4). 통 계 분석 결과 각 청력검사별로 반복 검사 시 위난청 기준에 해당하는 귀의 수에 유의미한 차이가 있는 것으로 나타났다

Table 1. Demographic data of the patients

\begin{tabular}{lcc}
\hline \multicolumn{1}{c}{ Characteristics } & $\begin{array}{c}\text { Total } \\
(\mathrm{n}=226)\end{array}$ & $\begin{array}{c}\text { True } \mathrm{HL}^{*} \text { group } \\
(\mathrm{n}=136)\end{array}$ \\
\hline ABR $(\mathrm{dB})$ & 74.47 & 71.67 \\
Age (year) & 69.85 & 73.98 \\
Sex & & \\
$\quad$ Male & $162(71.68)$ & $103(75.74)$ \\
$\quad$ Female & $64(28.32)$ & $33(24.26)$ \\
Hearing range by PTA (dB) & & \\
$40-59$ & $24(10.62)$ & $20(14.70)$ \\
$60-69$ & $101(44.69)$ & $90(66.18)$ \\
$70-79$ & $38(16.81)$ & $26(19.12)$ \\
$\geq 80$ & $63(27.88)$ & $0(0)$ \\
\hline
\end{tabular}

Data are presented as $\mathrm{n}(\%)$. *ears that do not satisfy current malingering criteria on repeated PTA and speech reception threshold test (40-80 dB). ABR: auditory brainstem response, $\mathrm{HL}$ : hearing loss, PTA: pure tone audiometry

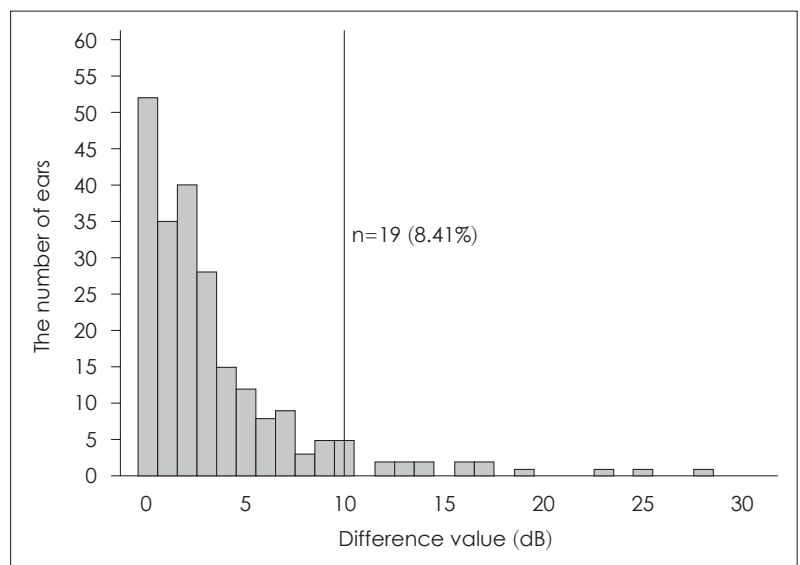

Fig. 2. Distribution of difference value in the repeated pure tone audiometry and the number of ears within malingering criterion. 
$(p<0.001)$ (Table 2)

전체 226개 귀의 어음명료도검사 간 편차값을 크기 순으로 나열하였을 때, 위난청 환자의 비율이 $10 \%$ 미만으로 나타나 는 기준값은 $21 \%$ 로, 해당 값에서 위난청 환자가 전체의 $9.79 \%$ 로 나타났다(Fig. 5). 보다 신뢰도 높은 위난청 기준값을 찾기 위해 ROC 곡선을 산출한 결과(Fig. 6), area under the curve (AUC) 값은 0.675 에 $p=0.002$ 로 의미 있는 검사법으로 확인되 었고, 최적 설정값(cut-off value)은 어음명료도 편차값 $8.5 \%$

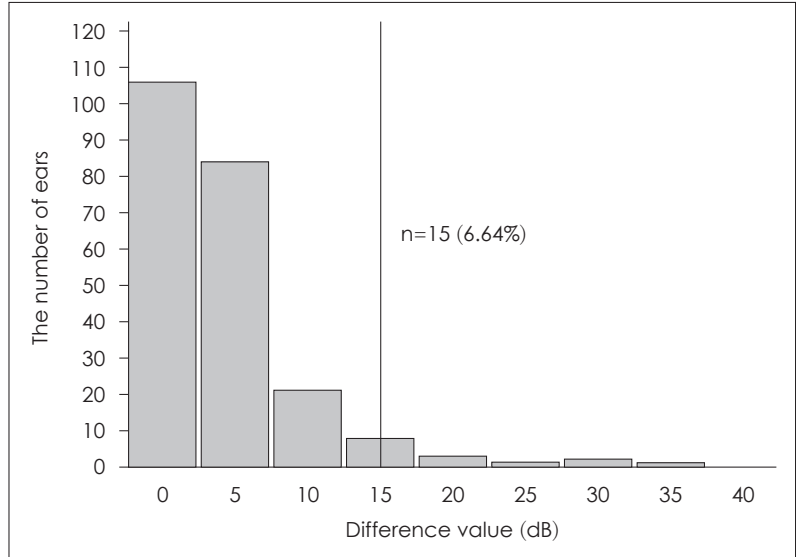

Fig. 3. Distribution of difference value in the repeated speech reception threshold test and the number of ears within malingering criterion.

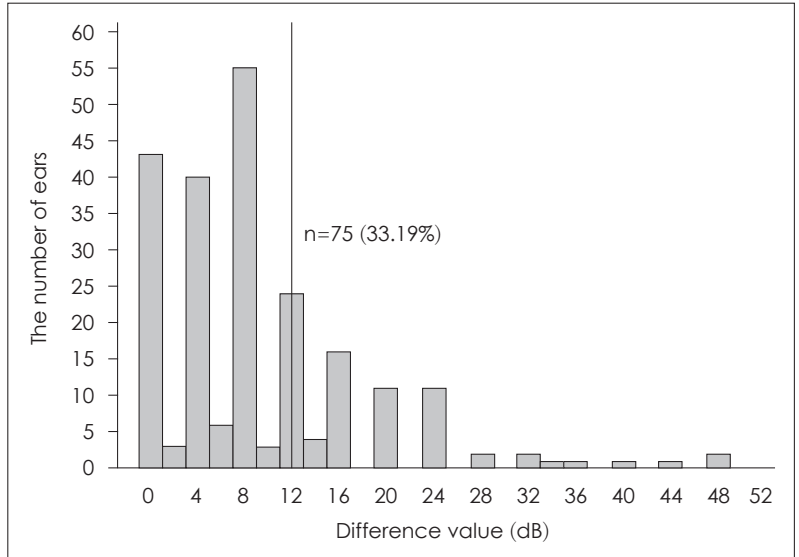

Fig. 4. Distribution of difference value in the repeated speech discrimination test and the number of ears within malingering criterion.

Table 2. Comparing the number of malingering ears for each repeated audiometry

\begin{tabular}{lcccc}
\hline \multicolumn{1}{c}{ Variable } & dPTA & dSRT & dSDT & p-value \\
\hline Normal (\%) & $207(91.59)$ & $211(93.36)$ & $151(66.81)$ & \\
Malingering (\%) & $19(8.41)$ & $15(6.64)$ & $75(33.19)$ & $<0.001$ \\
Mean & $3.49 \mathrm{~dB}$ & $4.12 \mathrm{~dB}$ & $9.39 \%$ & \\
SD & $4.46 \mathrm{~dB}$ & $5.59 \mathrm{~dB}$ & $8.94 \%$ & \\
\hline
\end{tabular}

dPTA: differences in pure tone audiometry tests, dSRT: differences in speech reception threshold tests, dSDT: differences in speech discrimination tests, SD: standard deviation
에서 민감도 $51.61 \%$, 특이도 $69.18 \%$ 로 나타나는 것을 확인하 였다. 기존 위난청 기준값 $12.0 \%$ 에서는 민감도 $51.61 \%$, 특이 도 $69.74 \%$ 로 확인되었고, 청각장애 진단에 적용하기 적합하 도록 특이도가 $90 \%$ 이상인 설정값을 확인한 결과, 어음명료 도 편차 $22.0 \%$ 에서 민감도 $25.81 \%$, 특이도 $92.82 \%$ 임을 확인 하였다(Table 3).

3 회 간의 어음명료도검사값 간의 차이가 $12 \%$ 미만인 군과 위난청 기준인 $12 \%$ 이상인 군 간의 차이를 확인하고자 선별 된 전체 귀 136 개를 대상으로 객관적인 청력 분포 차이를 확 인하기 위해 $\mathrm{ABR}$ 결과의 평균값을 비교하였다. $12 \%$ 미만 군 에서는 평균 $67.35 \mathrm{~dB}$, 위난청 군에서는 $68.87 \mathrm{~dB}$ 으로 나타 났고, $p=0.341$ 로 유의미한 청력의 차이는 나타나지 않았다

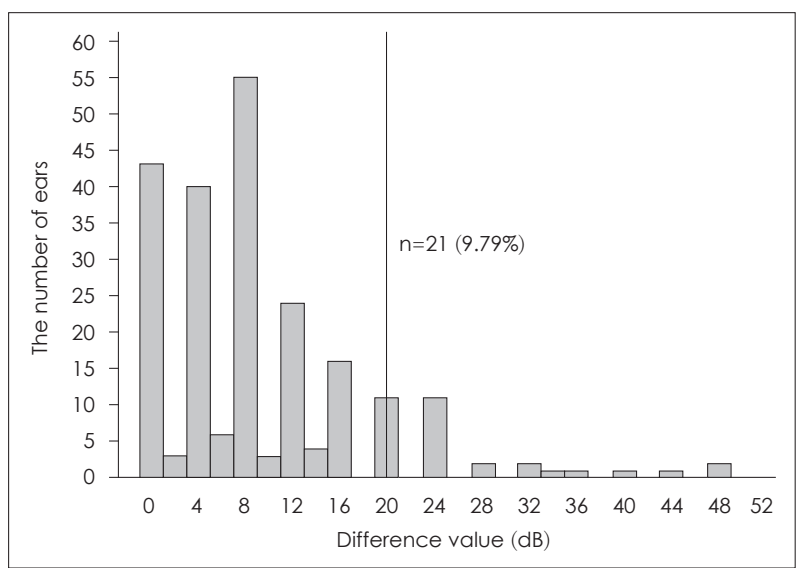

Fig. 5. Cut-off point that provides the proportion of malingering ears of less than $10 \%$.

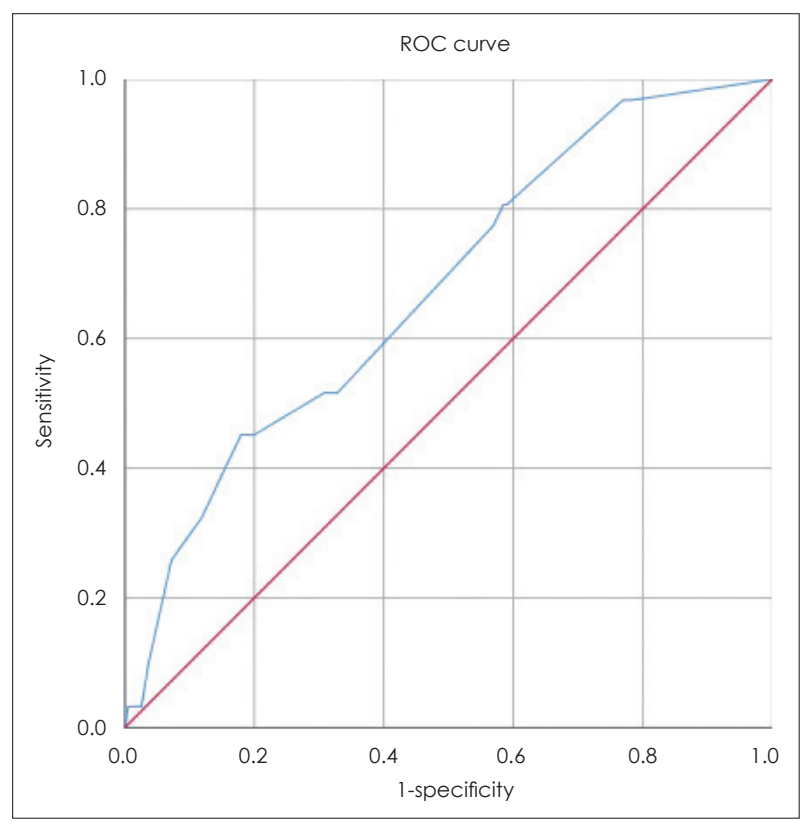

Fig. 6. ROC curve for prediction of appropriate cut-off value that prevents misdiagnosis as malingering. ROC: receiver operating characteristic. 
Table 3. Sensitivity and specificity of each cut-off point based on differences in repeated SDTs

\begin{tabular}{cccccc}
\hline Variable & $\begin{array}{c}\text { Cut-off } \\
\text { point }\end{array}$ & Sensitivity & Specificity & PPV & NPV \\
\hline Repeated SDT & 8.5 & 51.61 & 69.18 & 20.00 & 89.73 \\
& 12.0 & 51.61 & 69.74 & 21.33 & 90.07 \\
& 22.0 & 25.81 & 92.82 & 36.36 & 88.73 \\
\hline
\end{tabular}

SDT: speech discrimination test, PPV: positive predictive value, NPV: negative predictive value

Table 4. Comparing the characteristics between true $\mathrm{HL}$ group and malingering group based on speech discrimination tests malingering criteria in all selected ears

\begin{tabular}{lcccc}
\hline Variables & $\begin{array}{c}\text { True HL } \\
\text { group }\end{array}$ & $\begin{array}{c}\text { Malingering } \\
\text { group }\end{array}$ & Total & p-value \\
\hline ABR (dB) & 67.35 & 68.87 & & 0.341 \\
Age (year) & 74.90 & 72.53 & & 0.283 \\
Sex (\%) & & & & 0.954 \\
$\quad$ Male & $63(75.9)$ & $40(75.5)$ & $103(75.7)$ & \\
Female & $20(24.1)$ & $13(24.5)$ & $33(24.3)$ & \\
Total & 83 & 53 & 136 & \\
\hline
\end{tabular}

HL: hearing loss, $\mathrm{ABR}$ : auditory brainstem response

(Table 4). 두 군의 평균 나이는, $12 \%$ 미만 군이 74.90세, 위난청 군이 72.53 세였으며, 통계적 분석 결과 $p=0.283$ 으로 유의미 한 차이가 없는 것으로 확인되었다(Table 4). 성별 분포를 비 교해 본 결과, $12 \%$ 미만인 군에서는 남성 $75.9 \%$, 여성 $24.1 \%$ 로 나타났으며, 위난청 그룹에서는 남성 $75.5 \%$, 여성 $24.5 \%$ 로, 통계 분석 결과 $p=0.954$ 로 유의미한 차이가 없는 것으로 확 인되었다(Table 4).

세부 청력 범위 내 어음명료도의 위난청 군과 정상 난청 군 간의 차이를 확인해보고자 분류한 소그룹에서의 결과를 확 인하였다. 40 59 dB의 상대적 경도 난청의 청력 범위를 가진 소그룹에서 $12 \%$ 미만 군의 평균 $\mathrm{ABR}$ 역치는 $56.67 \mathrm{~dB}$, 위 난청 군은 $64.00 \mathrm{~dB}$ 로 위난청 군의 역치가 다소 높게 나타났 으나, 통계적으로 유의미한 차이는 나타나지 않았다 $(p=0.080)$ (Table 5). 평균 나이에서도 $12 \%$ 미만 군에서 65.80세, 위난청 군에서 76.13세로 위난청 군의 평균 나이가 10세 이상 높았으 나, 통계적으로 유의미하지 않았다 $(p=0.090)$ (Table 5). $12 \%$ 미만 군의 성별 분포는 남성 $66.7 \%$, 여성 $33.3 \%$ 였고, 위난청 군에서는 남성 $80.0 \%$, 여성 $20.0 \%$ 로 유의미한 차이는 없었다 ( $p=0.573$ ) (Table 5).

60 69 $\mathrm{dB}$ 의 중등도 난청 그룹에서의 평균 $\mathrm{ABR}$ 역치는 $12 \%$ 미만 군에서 $67.31 \mathrm{~dB}$, 위난청 군에서 $67.37 \mathrm{~dB}(p=0.969)$ 였고, 평균 나이는 $12 \%$ 미만 군에서 75.29 세, 위난청 군에서 73.92 세 $(p=0.608)$, 성별 분포는 각각 남성 $78.8 \%$, 여성 $21.2 \%$ 와 남성 $76.3 \%$, 여성 $23.7 \%$ 로 모두 통계적으로 유의미한 차 이를 나타내지 않았다 $(p=0.775)$ (Table 5).
Table 5. Comparing the characteristics between true $\mathrm{HL}$ group and malingering group based on speech discrimination tests malingering criteria in each hearing range

\begin{tabular}{ccccc}
\hline Variables & $\begin{array}{c}\text { True } \mathrm{HL} \\
\text { group }\end{array}$ & $\begin{array}{c}\text { Malingering } \\
\text { group }\end{array}$ & Total & p-value \\
\hline ABR $(\mathrm{dB})$ & & & & 0.080 \\
$40-59 \mathrm{~dB}$ & 56.67 & 64.00 & & 0.969 \\
$60-69 \mathrm{~dB}$ & 67.31 & 67.37 & & 0.971 \\
$70-79 \mathrm{~dB}$ & 76.88 & 77.00 & & 0.090 \\
Age (year) & & & & 0.608 \\
$40-59 \mathrm{~dB}$ & 65.80 & 76.13 & 0.740 \\
$60-69 \mathrm{~dB}$ & 75.29 & 73.92 & & 0.573 \\
$70-79 \mathrm{~dB}$ & 72.50 & 70.60 & & \\
Sex (\%) & & & & \\
$40-59 \mathrm{~dB}$ & & & & \\
Male & $10(66.7)$ & $4(80.0)$ & $14(70.0)$ & \\
Female & $5(33.3)$ & $1(20.0)$ & $6(30.0)$ & \\
$60-69 \mathrm{~dB}$ & & & & \\
Male & $41(78.8)$ & $29(76.3)$ & $70(77.8)$ & \\
Female & $11(21.2)$ & $9(23.7)$ & $20(22.2)$ & \\
$70-79 \mathrm{~dB}$ & & & & \\
Male & $12(75.0)$ & $7(70.0)$ & $19(73.1)$ & \\
Female & $4(25.0)$ & $3(30.0)$ & $7(26.9)$ & \\
\hline
\end{tabular}

$\mathrm{HL}$ : hearing loss, $\mathrm{ABR}$ : auditory brainstem response

70 79 dB 그룹에서는 $12 \%$ 미만 군에서 평균 $\mathrm{ABR}$ 역치 $76.88 \mathrm{~dB}$, 위난청 군에서 $77.00 \mathrm{~dB}$ 로 유의미한 차이가 없었 고( $p=0.971)$, 나이는 $12 \%$ 미만 군에서 72.50 세, 위난청 군에 서 70.60 세 $(p=0.740)$, 성별 분포는 $12 \%$ 미만 군에서 남성 $75.0 \%$, 여성 $25.0 \%$, 위난청 군에서 남성 $70.0 \%$, 여성 $30.0 \%$ 로 모두 유의미한 차이는 없었다( $p=0.780)$ (Table 5).

\section{고 찰}

본 연구에서 수집한 데이터상, 순음청력검사와 어음청취역 치의 반복 검사 간 편차가 위난청의 기준에 해당되는 환자의 비율은 6 8\% 수준인 것에 비하여, 어음명료도검사에서는 무 려 $33.19 \%$ 로 나타났다. 이는 순음청력검사와 어음청취역치 두 검사의 편차가 모두 정상 범위인 귀로 제한하였을 때도 전 체 148 개의 귀 중 48 개인 $32.43 \%$ 에서 위난청 범위의 어음명 료도 결과가 확인되었다. 이러한 결과를 통해, 난청 환자에서 는 실제 난청임에도 불구하고 반복 검사 시 현재 적용되고 있 는 어음명료도검사의 위난청 기준인 $12 \%$ 가 넘는 편차가 발 생할 수 있고, 이에 따라 장애 여부를 판단 시 실제 난청인 환자에서도 검사 간 편차가 발생하여 위난청으로 판단될 가 능성이 있음을 확인하였다.

본 연구에서는 어음명료도검사의 편차가 큰 환자군에서, 평균 나이가 높아 검사 일관성에 영향이 있거나, 평균 $\mathrm{ABR}$ 
역치값이 높아 어음 분별 능력에 영향이 있었을 가능성을 확 인하고자 어음명료도 편차의 위난청 범위 군과 정상 범위 군 간 통계 분석을 시행하였으나 두 군 간 성별, 나이, 청력 분포 에서 유의미한 차이가 없는 것으로 나타났다. 이러한 결과는 청력 범위를 40 59 dB의 상대적 경도 난청 그룹과 60 69 $\mathrm{dB}, 70 \sim 79 \mathrm{~dB}$ 의 중등도 난청 그룹으로 소분류하여 비교하 였을 때도 마찬가지로 통계적으로 유의미한 차이는 없었으나, 40 59 dB 그룹에서 다른 그룹에 비해 ABR 역치값의 차이 가 위난청 군에서 약 $8 \mathrm{~dB}$ 로 보다 높게 나타났으며, 평균 나 이도 위난청 군에서 약 10 세 이상 높은 것을 확인하였다. 이 를 통해 난청 환자에서는 실제 난청임에도 불구하고, 어음명 료도검사 간의 편차가 클 수 있을 뿐만 아니라 특히 장애 진 단의 주 대상이 되는 고령의 중등도 이상 난청 환자일수록 현재 위난청 기준으로 사용되고 있는 기준 값인 $12 \%$ 를 초과 하는 편차가 발생할 가능성이 높아, 청각장애 진단에 적용되 기에는 부적합할 수 있다는 근거가 될 수 있다.

난청환자에서 어음명료도 반복 검사 간의 편차가 크게 측 정되는 원인으로 몇 가지 가능성을 고려해 볼 수 있다. 첫 번 째는 연구대상으로 선정된 환자들이 청각장애 진단을 위해 내원한 평균 나이 69.8세의 노인성 난청 환자가 대다수라는 점이다. 1991년 Humes 등 ${ }^{4}$ 의 연구에 따르면, 노인성 난청은 대개 고주파수 영역대의 감각신경성난청을 나타내어 다른 난 청에 비해 서로 다른 주파수를 구별하는 능력이 저하되고 중 추신경계의 노화로 인해 어음 분별 능력이 저하된다고 알려 져 있다. 1992년 Van Rooij와 Plomp ${ }^{5}$ 는 노인에서 고주파수 청력 손실 정도가 어음 분별의 차이를 유발하는 원인이라고 하였으며, 난청의 정도별 그룹에 따라서(26 35 dB, 36 45 $\mathrm{dB}, 46 \sim 55 \mathrm{~dB}$ ) 어음분별력에 유의미한 차이를 확인하였다. 2012년 $\mathrm{Han}^{6}$ 이 연구한 노인성 난청의 음절 지각에 관한 연 구에 의하면, 같은 환자에서 유사한 난청의 정도 및 형태를 가지고 있는 양측 귀에 같은 음절을 들려주었을 때, 양측 귀 의 음절별 오류율이 상이한 것을 확인하였다. 이와 같은 결과 들을 통해, 노인성 난청 환자에서는 어음 분별 능력이 난청 정도에 따라, 심지어는 같은 환자에서도 검사 시마다 결과에 차이를 나타낼 가능성이 있음을 확인할 수 있다.

두 번째는 연구에 포함된 환자들의 대다수가 중등도 난청 환자로서, 문진상 이명을 동반하고 있었다는 점이다. 2018년 Liu 등ㄱㅇㅣ 수행한 연구에 따르면, 이명의 유무와 난청의 지속 정도가 소리의 위치 파악 및 음성 인식 능력에 영향을 미치 며, 이명이 있는 난청 환자에서 음성 인지 능력이 더 감소하는 것으로 확인되었으며, 2013년 Mertens 등이이 수행한 일측성 난청 환자에서의 이명과 어음 청취 간의 관계에 관한 연구 결 과, 인공와우 수술을 시행한 환자를 대상으로 인공와우를
비활성화하거나 활성화하여 난청 측 귀의 이명 수준을 변경 할 때, 반대측 귀에서의 어음 수신 능력이 크게 변화하는 것 을 확인하였다. 본 연구에서는 이명도검사를 필수적으로 시 행하지 않아 이명의 정도에 따른 어음명료도검사 간 편차의 관계를 확인하기에는 제한점이 있으나, 각 환자에서 이명의 정도에 따라, 또한 같은 환자에서도 수일 간격을 두고 시행하 는 반복 검사의 특성상 검사 시의 이명의 정도에 따라 단음 절의 단어를 인지하는 능력에 차이를 보였을 수 있다.

세 번째는 검사의 일관성에 대한 부분이다. 2012년 $\mathrm{Han}^{6}$ 의 연구에 따르면, 같은 환자에서 같은 음절을 이용한 검사 시에 도 검사자의 성별에 따라 같은 음절도 정답률이 $60 \%$ 까지 차 이가 발생하는 것을 확인하였다. 현재 어음명료도 검사는 검 사자가 단음절어표에 있는 단어를 직접 읽어주고 피험자가 따라 말하도록 하고 있는데, 반복 검사 시 검사자에 따라 결 과에 차이를 보일 수 있고, 같은 검사자라 할지라도 일정하게 녹음된 소리가 아니므로 항상 같은 소리를 내지 못할 수 있 다. 또한 2013년 Baek 등)이 수행한 노인성 난청 환자의 단어 인지도 특성 분석에 의하면, 같은 환자에서 음절에 따라 정답 률의 차이를 나타낼 수 있음을 확인하였고, 따라서 환자의 반 복 검사 시 읽어주는 50 개 음절의 세트가 변화한다면, 음절의 특성상 편차를 보일 가능성 역시 존재한다.

추가적으로 어음명료도검사 자체에 대해 고찰해볼 필요가 있다. 현재 우리나라의 어음명료도검사는 1962년 $\mathrm{Hahm}^{3}$ 이 일상생활에서 사용되는 한국어 단음절어를 중심으로 유의미 단음절 200개를 50 개씩 4개의 리스트로 구성한 것을 첫 시도 로, 이후에도 많은 한글 단음절어표를 개발하는 시도가 있어 왔으나, 아쉬운 점은 아직도 60 여년 전에 개발된 함태영 어표 가 가장 널리 사용되고 있으며, 전국의 청각장애 검사를 시행 하는 병원 및 의원의 어음명료도검사 단음절어표가 통일되지 않았다는 점이다. 2007년 Park 등이이 현대에 다빈도로 사용 되는 음절들과 함태영 어음표를 비교하여 음절들의 주파수 별 분포 및 특성을 연구한 결과, 함태영 어음표는 현대 회화 에서 주로 사용되는 음절의 반영이 미흡하고, 특히 노인성 난 청에서 많은 저하를 보이는 고주파수 영역을 적절히 평가하 지 못하는 것으로 나타났으며, 2005년 Byun 등1)이 발표한 전국 수련병원에서 사용하고 있는 한국어 단음절어표에 대 한 실태에 따르면, 전국 80 개 수련병원에서 총 13 종의 다양한 단음절어표가 사용되고 있는 것으로 확인되었다. 이처럼 오 래된 어표가 현대에 사용되기에는 제한점이 있을 수 있고, 검 사실 간 통일되지 않은 어표의 사용은 검사실 환경에 따라서 도 차이를 유발할 수 있을 것이다.

본 연구의 제한점은, 첫 번째로 청각장애 진단을 위해 내원 한 중등도 이상의 난청 환자만을 대상으로 분석하였다는 점 
이다. 본 연구에서는 두 귀의 청력 손실이 $80 \mathrm{~dB}$ 이상인 환자 의 데이터는 제외시켰는데, 이는 고도 난청 환자의 데이터 분 석 시 대부분 어음명료도가 거의 $0 \%$ 에 수렴하여 편차가 없 는 양상을 보여 분석에 적합하지 않았기 때문이다. 또한 40 $59 \mathrm{~dB}$ 의 상대적 경도 난청 환자 그룹에서는 평균 $\mathrm{ABR}$ 과 나 이에서 위난청 군과 정상 난청 군 간 평균 차이가 중등도 난 청 그룹에서보다 크게 나타났다. 이와 같은 결과를 비추어 볼 때, 현재 시행한 연구 결과상 중등도 난청 환자에서는 현재 위난청 기준하에 유의미한 차이를 보여주지 못했으나, 청력이 정상이거나 경도 난청을 가진 환자에서는 다른 결과가 나타 날 가능성이 있으며, 추가 연구를 통해 환자의 청력 수준에 따라 다르게 적용되는 유동적인 어음명료도의 위난청 기준 이 필요할 수 있다.

두 번째는 본 연구에서는 환자들의 동반 질환 및 과거력에 대한 조사가 결여되었다는 점이다. 본 연구에서는 성별, 나이, 청력, 장애 등급 등 모든 환자들의 일반적 특성에 대한 차이 만을 분석하였으나, 환자들의 인지능력과 관련된 동반 질환 여부와 귀와 연관된 과거력 및 수술력이 어음 분별력에서 편 차를 나타낼 수 있는 요인이 될 수 있다. 2007년 Humes 등리 의 연구에 따르면, 노인에서 뇌졸중이나 알츠하이머씨병과 같은 중추신경장애 및 인지기능장애를 동반하는 경우 난청 만 있는 환자에 비해 언어 이해력이 저하되었으며, 2020년 Chung ${ }^{13)}$ 이 연구한 노화성 난청과 인지기능 저하의 연관성에 관한 연구에 따르면, 노화성 난청의 지속 자체가 인지 기능 저 하의 원인이 될 수 있어, 이는 검사자가 불러주는 말을 따라 하는 능동적인 과정이 필요한 어음명료도검사에서 검사 마다 결과의 차이를 나타내는 원인이 될 수 있을 것이며, 노인에서 장애등급검사 진행 시 이러한 기저질환에 대한 고려가 반영 되어야 할 것이다.

환자의 위난청을 감별할 수 있는 방법에는 반복청력검사, 순음청력검사와 어음청취역치 간의 역치 차이를 확인하는 방 법 및 특수검사로서, Bekesy 청력검사, Lobard 검사, Stenger 검사, 교대문장검사 등이 존재하지만, 어음명료도의 위난청 감별은 반복 검사를 통한 비교 방법이 유일하다. 그러나 현재 사용되고 있는 위난청 기준은 40 여년 전 해외 연구를 바탕으 로 설정된 기준이며, ${ }^{2)}$ 따라서 현대의 한글 어음 검사에 적용 시키기에는 부적절할 수 있다.

본 연구에서 수집된 226개의 귀 데이터를 바탕으로 어음명 료도검사에서 위난청 환자 비율이 $10 \%$ 미만 수준에 해당하 는 어음명료도검사 편차의 기준값은 $21 \%$ 로 나타났고, $\mathrm{ROC}$ 곡선을 통해 산출한 $90 \%$ 이상의 특이도를 보이는 기준값도 유사한 수치인 22\%인 것으로 확인되었다. 그러나 보다 신뢰 도 높은 ROC 곡선과 기준값을 제시하기 위해서는 위난청의
확진 검사 결과가 필수이나, 현재 위난청을 감별하는 여러가 지 방법에도 불구하고 정확한 확진 검사로 정립된 것이 없는 제한점이 존재했다. 그러나 본 연구에서 확인된 기준값들을 바탕으로, 중등도 난청 환자에서는 현재의 기준인 $12 \%$ 와는 다른 기준이 필요할 수 있음을 확인하였고, 따라서 향후 추 가적인 연구를 통해 한글 어음 검사에서 적용 가능하며 난청 환자에서 최소한의 편차를 나타내는 위난청 기준 설정이 필 요할 것이다.

결론적으로, 현재 통용되고 있는 위난청 기준하에서, 어음 명료도검사에서만 유의미하게 많은 위난청 기준 내의 환자가 확인되었으나, 위난청으로 분류된 군에서 특징 지을 만한 유 의미한 차이가 없음을 확인하였다. 따라서 중등도 난청 환자 에서는 어음명료도검사 시 실제 난청임에도 불구하고 현재 의 위난청 기준에 해당하는 편차를 유발할 가능성이 있으므 로, 청각장애 판단 시 현재 위난청 기준에 대한 재평가가 필 요하다.

\section{Acknowledgments}

None.

\section{Author Contribution}

Conceptualization: Taehun Lim, Joo Hyung Oh, Junho Hwang, Joon Bum Joo, Jong Yang Kim. Data curation: Taehun Lim, Joo Hyung Oh, Junho Hwang. Formal analysis: Taehun Lim, Ju Eun Cho, Jong Yang Kim. Funding acquisition: Taehun Lim, Joon Bum Joo, Jong Yang Kim. Investigation: Taehun Lim, Joo Hyung Oh, Junho Hwang. Methodology: Ju Eun Cho, Jong Yang Kim. Project administration: Jong Yang Kim. Resources: Taehun Lim, Joon Bum Joo. Software: Taehun Lim, Junho Hwang. Supervision: Jong Yang Kim. Visualization: Taehun Lim. Writing - original draft: Taehun Lim. Writing — review \& editing: Taehun Lim.

\section{ORCIDs}

Jong Yang Kim

Taehun Lim

https://orcid.org/0000-0001-6067-6182

https://orcid.org/0000-0003-4540-0262

\section{REFERENCES}

1) Chaiklin JB, Ventry IM. Patient errors during spondee and pure tone threshold measurement. J Aud Res 1965;5:219-30.

2) Hodgson WR. Basic audiologic evaluation. Malabar, FL: Krieger Publishing Company; 1980.

3) Hahm T. Korean word list for speech audiometry and results of articulation test. J Catholic Med College 1962;6:31-6.

4) Humes LE, Nelson KJ, Pisoni DB. Recognition of synthetic speech by hearing-impaired elderly listeners. J Speech Hear Res 1991; 34(5):1180-4.

5) van Rooij JC, Plomp R. Auditive and cognitive factors in speech perception by elderly listeners. III. Additional data and final discussion. J Acoust Soc Am 1992;91(2):1028-33.

6) Han W. Case study of speech perception in presbycusis. Audiology 2012;8(1):116-22.

7) Liu YW, Cheng X, Chen B, Peng K, Ishiyama A, Fu QJ. Effect of tinnitus and duration of deafness on sound localization and speech recognition in noise in patients with single-sided deafness. Trends 
Hear 2018;22:2331216518813802.

8) Mertens G, Kleine Punte A, De Ridder D, Van de Heyning P. Tinnitus in a single-sided deaf ear reduces speech reception in the nontinnitus ear. Otol Neurotol 2013;34(4):662-6.

9) Baek HJ, Shim HY, Kim J. An analysis of characteristics for word recognition scores in geriatric hearing loss. Audiology 2013;9(1): 49-59.

10) Park MK, Lee JH, Kwon HS, Im GJ, Woo JS, Lee HM, et al. A study for the acoustic characteristics of PB word list according to frequency. Korean J Otolaryngol 2007;50(6):480-5.

11) Byun SW, Chung SM, Kim HS, Go YM. A survey of phonetically balanced words lists used in training hospitals in Korea. Korean J Otolaryngol 2005;48(9):1086-90.

12) Humes LE, Burk MH, Coughlin MP, Busey TA, Strauser LE. Auditory speech recognition and visual text recognition in younger and older adults: Similarities and differences between modalities and the effects of presentation rate. J Speech Lang Hear Res 2007; 50(2):283-303.

13) Chung J. Association of age-related hearing loss with cognitive decline. Korean J Otorhinolaryngol-Head Neck Surg 2020;63(4): $145-53$. 